Volume 3, Number 1, December 2021

Journal of Research on Mathematics Instruction

Journal's Webpage: http://jrmi.ejournal.unri.ac.id

\title{
Analysis of Students' Mathematical Communication Ability on Set Materials Based on Gender Differences
}

\author{
Rodhitul Amni \\ Universitas Riau, INDONESIA
}

ARTICLE'S

INFORMATION

Article history:

Received: Nov-17-2021

Reviewed: Dec-01-2021

Accepted: Dec-27-2021

Keywords: Gender,

Mathematical Communication Ability, Set

\begin{abstract}
The study was conducted to determine the students' mathematical communication skills in the set material. In doing math problems, there are still many students who make mistakes in solving the questions given by the teacher. Students' difficulty in answering questions, one of which is influenced by mathematical communication skills. The method used is descriptive qualitative, which is analyzed from the instrument in the form of 5 written test questions in the form of description questions. The subjects studied were 22 students. This research was conducted on Thursday, October $21^{\text {st }}$ 2021, at Madrasah Tsanawiyah Al Muhajrin Tapung, 2021/2022, totalling 13 female and nine male students. In this study, there are three indicators used, namely 1) mathematical expressions, which are everyday events that are expressed in mathematical concepts and mathematical symbols, 2) drawing, which is mathematical ideas that can be expressed in terms of mathematical concepts. In the form of pictures, and 3) writing (written text) that can show and explain everyday events into mathematical models and mathematical language. From the results of mathematical communication skills based on gender with these three indicators, female students have higher mathematical communication skills than male students. The average percentage for female students is $70.8 \%$, and the percentage of male students is $52.75 \%$. The results of the conversion of scores in the very low category for male students and medium category for female students.
\end{abstract}

\section{Corresponding address:}

Rodhitul Amni,

E-mail: rodhitul.amni7398@grad.unri.ac.id

\section{INTRODUCTION}

Learning mathematics with mathematical communication skills is needed. Students must possess communication skills to convey thoughts or ideas in the form of mathematical symbols or mathematical language. Students can have mathematical communication skills if they can express mathematical problems or events in the form of mathematical symbols, pictures, graphs, or mathematical language. Kramarski in [1] states that mathematical communication is like a verbal explanation. In mathematical reasoning, three dimensions can be measured: correctness, fluency to state several correct answers, and mathematical representations in visual, algebraic, diagrammatic, and formal forms. In line with that, Hendriana \& Sumarmo, in [2] stated that the need for mathematical communication skills in mathematics learning so that it can help hone ways of thinking, measure understanding, can help them grow their mathematical knowledge, optimize problem-solving skills, express reasoning, realize self-ability, generate social skills, able to be useful for building mathematical communication. It can be seen in the purpose of the mathematics learning process that has been designed by the National Council of Teachers of Mathematics [1] which is to develop students' abilities in solving mathematical problems, mathematical reasoning, and mathematical communication.

The students must master Communication skills in every mathematics lesson in interacting with 
their environment. In this communication activity, students can exchange ideas or suggestions, then communicate each result of the students' thoughts. Learning should emphasize activities that can foster mathematical communication so that students have communication skills so that interactions run well and solve problems to achieve other mathematical abilities such as reasoning, connection, understanding, and problem-solving. The learning process in the classroom to understand mathematical communication, stated by Baroody in [3], is the initial capital to complete, invest, and explore mathematics which is a means for social activities with friends, exchanging ideas and discoveries, exchanging opinions, assessing and hone ideas to give confidence to those around them. Sumarno 2017 in [4] states that mathematical communication skills include: linking real objects, diagrams and pictures, to the form of mathematical ideas, explaining ideas, existing conditions, mathematical relations in writing or verbally on real objects, algebra, pictures, and graphs. They express daily events in the language, symbols, mathematical models, listening, discussion and writing related to mathematics, reading in understanding a written mathematical presentation, compiling various mathematical questions relevant to the problem, making conjectures, stating arguments, formulating definitions and generalizations.

In solving math problems, communication skills need to be developed again, considering that communication is an activity that is indispensable in everyday life. Because in this communication there is an activity of getting information, in the form of messages, writings, inspiration or ideas, from one party to another. Usually, communication activities are often carried out verbally to understand each other between the two parties [5]. The need for communication is also expressed by [6]. Communication Skills are abilities that need to be mastered by students to learn mathematics. Elementary school (SD) and junior high school (SMP) are expected to master good communication skills. According to the NCTM or National Council of Teacher mathematics [7], mathematics learning has five competencies: problem-solving, connection, communication, representation, and mathematical reasoning. Among the five, the focus according to the competencies conveyed is mathematical communication skills.

Mathematical communication skills need to be trained on students. The study results [8] stated that there were two causes of learning difficulties in mathematics, namely 1) conceptual difficulties and verbal difficulties. Low skills of mathematical communication are the cause of these difficulties. Some similar studies too revealed low mathematical communication skills. One of them is from research conducted by [9] which states that students' communication skills are still relatively low. Another study [10] found that mathematical communication skills in visual learning styles were in a low category.

Similarly, in the research [11], this ability is classified as very low at the junior high school level on the material of quadrilaterals and triangles. One of the causes is that teachers tend to use the lecture method whose learning activities are more focused on the teacher (teacher-centred learning) so that student communication is lacking [12]. The same study, conducted by Nurhayati (2014) in [13], found the low communication skills of students. Because when learning takes place, students are less active. Most students get a score not more than $60 \%$. As a result, the quality or achievement of students' mathematical communication skills has not been achieved with the desired category. The results obtained by students are still not perfect or wrong in answering the questions that the teacher has given. This is in accordance with research [14]. In some schools, many students still make mistakes in doing math problems. Because students are less able to communicate the teacher's questions. From the research done by [14] to measure students' communication ability, each problem number represents one indicator and uses the same problem to measure the communication ability of all 
indicators [15]. In contrast to this research conducted, where to find out the mathematical communication skills, students use two different problems to measure each indicator of mathematical communication skills.

Ansari: 2012 in [16] states that three groups of indicators can measure mathematical communication skills, namely: 1) Mathematical expressions, expressing concepts in mathematics in symbols, and language from everyday events, 2) drawing is expressing concrete objects, diagrams, and pictures into mathematical ideas or vice versa, and 3) writing text, expressing students' answers in their language, making a model, or problem using written, spoken, graphic, and written language. In algebraic form, explaining and realizing questions related to mathematics, heeding, discussing, and writing about mathematical material, then realizing conjectures, ordering arguments, and generalizations.

Another factor that influences students' mathematical views or communication about mathematics is gender [17], [18]. Sex differences (gender) can influence or psychological differences when learning students. So that female and male students certainly have differences when studying mathematics [19]. Nurfauziah \& Fitriani: 2019 in [20] stated that men and women are diverse when working on a mathematical problem or event, one of which is a mathematical abstraction. Another cause is differences in behaviour, emotional, intelligence, and mindset of each female or male student.

Research [21] states that male students have lower scores than female students on all indicators. Female students are more thorough when working on mathematical problems or problems. Compared to male students, they can express mathematical ideas in symbols, pictures, or diagrams and have a very good mathematical representation. The mathematical communication ability of female students is higher than that of male students, with a difference of $17.42 \%$. Research by [22] states that differences in students' mathematical abilities from gender roles can affect mathematical abilities. Women's communication skills are superior both orally and in writing. Research conducted by Ainul Hikmah found that the low level of students' mathematical understanding skills was caused by their low reading and writing skills [15].

In everyday life, there are many things related to the set. A set can be declared if the collection or group can be clearly defined. One example in a class is stating the number or number of students. There is a group of students who like math, students who like physics, and a group of students who like math and physics. Then the problem can be stated as a set because it consists of several groups and can also be expressed in mathematical language. In addition to these problems, other problems are related to the set material that we often encounter in our daily lives. The description above shows the need for students to have mathematical communication skills in learning, so researchers are interested in analyzing students' skill of mathematical communication in the set of material based on gender. So from the description above, the purpose of the research was to find out the students' mathematical communication skills on the material set based on gender in class VII in madrasah Al Muhajirin tapung.

\section{METHODS}

This research is qualitative research using descriptive methods to provide an overview and description of students' mathematical communication from the results of students' answers. Class VII for the academic year 2021/2022, which consists of 22 students consisting of 13 female students and nine male students, were selected as research subjects in this study. This research was conducted on Thursday, October $21^{\text {st }} 2021$, at Madrasah Tsanawiyah Al Muhajirin Tapung. The research procedure 
goes through several stages: 1) the preparation of mathematical communication skills test questions, 2) provides tests and collects test results, 3) analyzes test results, 4) concludes. To determine the category of test results indicators of students skills of mathematical communication in the form of essay problems. According to [16], essay questions can be used to assess mathematical communication skills. The questions given are in the form of essay questions on a validated set of 5 questions. Each indicator of communication ability represents two questions of each indicator. The first indicator uses the number 1 and number 2, the second one uses the number 2 and number 5 , and the third one uses the number 4 and number 5 . Analysis of student work based on gender was carried out by calculating the average and percentage of male and female students for each indicator, describing from the data collected, and making conclusions called descriptive statistics. To analyze students' answers, using a scoring technique for communication skills questions based on holistic scoring rubrics from [23], namely:

Table 1. Mathematical Communication Ability Scoring

\begin{tabular}{|c|c|}
\hline Score & Criteria \\
\hline 4 & $\begin{array}{l}\text { Perfect, clear or complete in answering all aspects of questions about mathematical } \\
\text { communication skills }\end{array}$ \\
\hline 3 & Correct in answering almost all aspects of questions about communication skills. \\
\hline 2 & Correct in answering some aspects of questions about communication skills \\
\hline 1 & $\begin{array}{l}\text { Incorrect conclusions in answering or not following aspects of questions about } \\
\text { communication skills }\end{array}$ \\
\hline 0 & No answer \\
\hline
\end{tabular}

Then, the results of the percentage scores were categorized into very low, low, medium, high, and very high. This category uses the assessment conversion [24].

Table 2. Score Conversion

\begin{tabular}{ll}
\hline \multicolumn{1}{c}{ Category } & \multicolumn{1}{c}{ Percentage } \\
\hline Very high & $90,00 \leq \mathrm{P} \leq 100$ \\
Tall & $80,00 \leq \mathrm{P}<90,00$ \\
Currently & $65,00 \leq \mathrm{P}<80,00$ \\
Low & $55,00 \leq \mathrm{P}<65,00$ \\
Very low & $\mathrm{P}<55,00$
\end{tabular}

After all the data from the test results of students' mathematical communication skills were analyzed, it can be concluded that the description of the level of students' communication skills on the set material. The indicators of skills of mathematical communication used in this study refer to research [25] and are simplified again into 1) mathematical expressions are everyday events expressed in mathematical concepts and mathematical symbols, 2) drawing is that mathematical ideas can be expressed in the form of pictures, and 3) writing is being able to show and explain everyday events into mathematical models and mathematical language.

\section{RESULTS AND DISCUSSION}

The results of the communication skills test given to 9 male students and 13 female students, from the three indicators tested based on gender, the data presented in Table 3. 
Table 3. Mathematical Communication Ability Scores of Male and Female Students

\begin{tabular}{|c|c|c|c|c|}
\hline No & Aspects & Indicators & $\begin{array}{c}\text { Female Students } \\
\text { Average Score (\%) }\end{array}$ & $\begin{array}{c}\text { Male Students } \\
\text { Average Score ( } \%)\end{array}$ \\
\hline 1 & $\begin{array}{l}\text { Mathematical } \\
\text { expression }\end{array}$ & $\begin{array}{l}\text { Expressing everyday events into } \\
\text { mathematical concepts and } \\
\text { mathematical symbols }\end{array}$ & 80,75 & 65,25 \\
\hline 2 & Drawing & $\begin{array}{l}\text { Expressing mathematical ideas } \\
\text { in the form of pictures }\end{array}$ & 59,55 & 31,9 \\
\hline 3 & Writing text & $\begin{array}{l}\text { Demonstrating and explaining } \\
\text { everyday events into } \\
\text { mathematical models and } \\
\text { mathematical language }\end{array}$ & 72,1 & 61,1 \\
\hline & & Total & 70,8 & 52,75 \\
\hline
\end{tabular}

In describing students' communication skills in the Association based on gender, the analysis of the results of students' answers is guided by indicators of students' skills of mathematical communication based on gender differences, as follows:

1. Expressing everyday events into mathematical concepts and mathematical symbols

Based on the Aspects table on mathematical expressions, female students are higher than male students. The percentage of the average value is $65.25 \%$. The communication ability of male students is in the medium category because it lies in the range of $65.00 \mathrm{P}<80.00$. Meanwhile, the average percentage of female students is $80.75 \%$. The communication ability of female students is in the high category because it lies in the range of $80.00 \mathrm{P}<90.00$ with a difference in the percentage of male and female students of $15.5 \%$. Subjects for male students and female students were taken on questions number 1 and number 3 for examples of student answers. The problems are: (1) If $A=\{x \mid 5 x 9, x$ natural numbers $\}$ and $B=\{x \mid 7 x<13$, $x$ whole number $\}$, then $A \cup B$ is? Express it in mathematical symbols and give the reason! Problem number $2 \mathrm{~S}=\{\mathrm{x} \mid \mathrm{x}$ natural numbers less than 12$\} \mathrm{B}=\{$ even numbers less than 12$\}$. Then the complement of the set B? Express in mathematical symbols, solve and give reasons! Below is a sample image of the students' answers. 


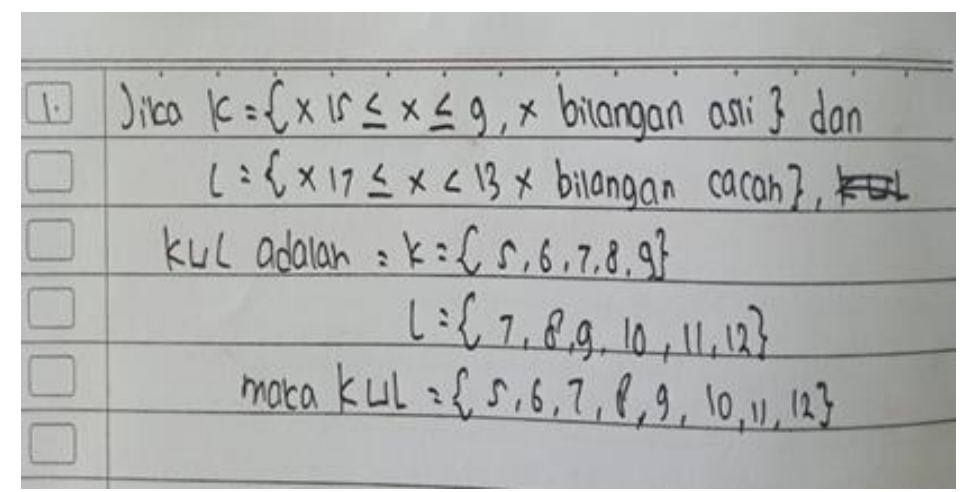

Figure 1. The answer of female students for question number 1

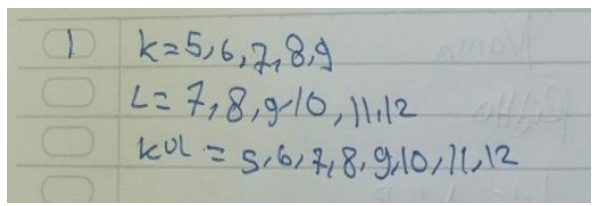

Figure 2. Answers of male students for question number 1

Figure 1 shows the results of the answers that female students can determine concepts and express mathematical symbols, write each member of the set correctly and the use of symbols or rules in writing in the set is complete, reading comprehension of what is meant in the problem is good. However, it has not stated the reason for the answer. While Figure 2, the male students' answers show that they are less able to determine concepts and express mathematical symbols. The rules in writing or declaring a set by registering the members are not written down. So that male students do not make or declare a set correctly. This shows that male students are lower in expressing concepts by stating events in a mathematical model when compared to female students.

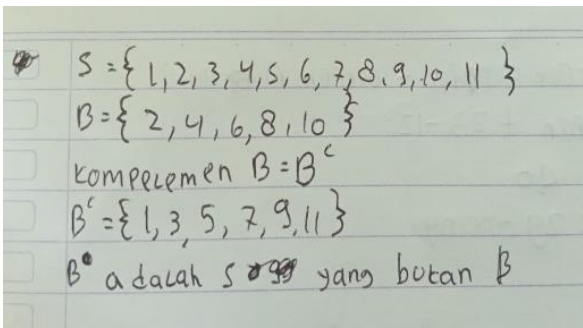

Figure 3. Answers of female students for question number 3

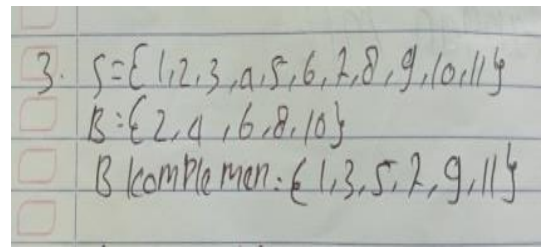

Figure 4. Answers of male students for question number 3

From Figure 3, it can be seen that the results of female students' answers have been able to determine concepts and express mathematical symbols, have a good understanding of what is meant by the problem, can state the reasons for the answers they are working on even though they are not perfect and need to be improved. While Figure 4 shows that male students are less able to express mathematical symbols, the answer still uses the word "complement" or has not changed the 
complementary sentence to its mathematical symbol. The answer is correct. Still, it has not been able to make an excuse for the answer. This shows that male students are lower in expression indicators or concepts by stating problems in symbols or mathematical models than female students. This is in line with research [24], which states that female students are higher in indicators in expression to express mathematical concepts with mathematical symbols than male students. It is also different from the Ekasari 2017research in [26], which states that male students are more capable than female students of expressing mathematical ideas orally. This difference could be due to other factors, such as interests, talents, and learning styles of students, both female and male students.

2. Expressing mathematical ideas in the form of pictures

For the drawing aspect, female students are higher when compared to the average results. It can be seen that the average result of the drawing aspect is $31.5 \%$ male students and belongs to the very low category, with the percentage category of $\mathrm{P}<55.00$. And $59.55 \%$ obtained the average percentage of women who belong to the low category. The difference between male and female students is $27.65 \%$. The subjects selected were female and male students in questions number 2 and 5, for examples of student answers. (2) It is known that $\mathrm{P}=\{2,3,5,7,10,12\}$ and $\mathrm{Q}=\{1,3,5,7$, 9 \} determine the result $\mathrm{P}-\mathrm{Q}$, explain and draw it in the form of a Venn diagram! (5) Of the 40 participants in the competition, 23 participants in the poetry reading competition, 12 participants in the poetry reading competition, and writing short stories. Determine the number of participants who participate in the short story writing competition, and explain and state the problem in the form of a picture! Below are the results of the students' answers.

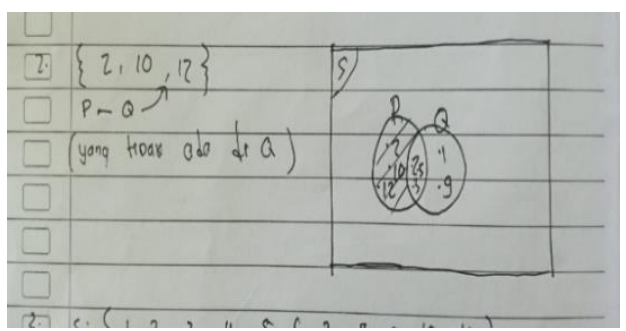

Figure 5. Answers of female students for question number 2

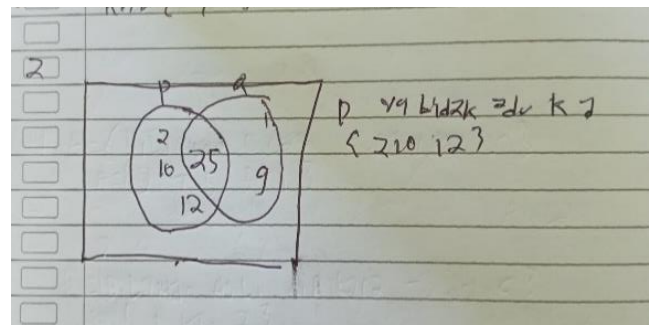

Figure 6. Answers of female students for question number 2

From Figure 5, it can be seen that the results of female students' answers have been able to make mathematical ideas into image form in the form of Venn diagrams whose results have been shaded and the shape of the Venn diagram is quite good, understanding in terms of what is meant by the question is good, and able to provide explanations through pictures. About the difference in the two sets even though the sentences or writings made need to be corrected again. And for male students' answers, they have been able to make ideas into pictures, but they are not perfect because the requests from the questions have not been clearly illustrated, which results are the difference between the two sets on the Venn diagram. And pictures or Venn diagrams do not fully fulfil, because the provisions in making Venn diagrams are not perfect; namely, the writing for the universe set does 
not yet exist, the Venn diagram is made untidy, each member of the set has not been marked with a dot, and an explanation for the answer to the question is still lacking. Perfect, and it has not shown the difference between the two sets.

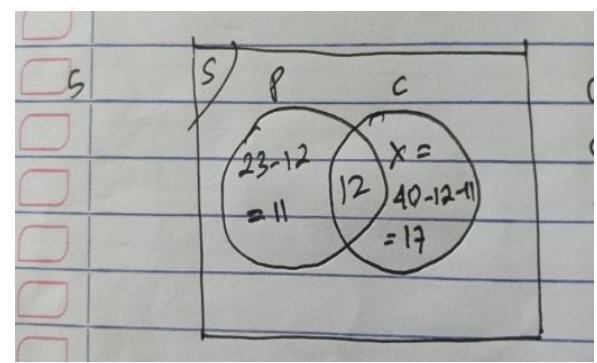

Figure 7. Answers of female students for question number 5

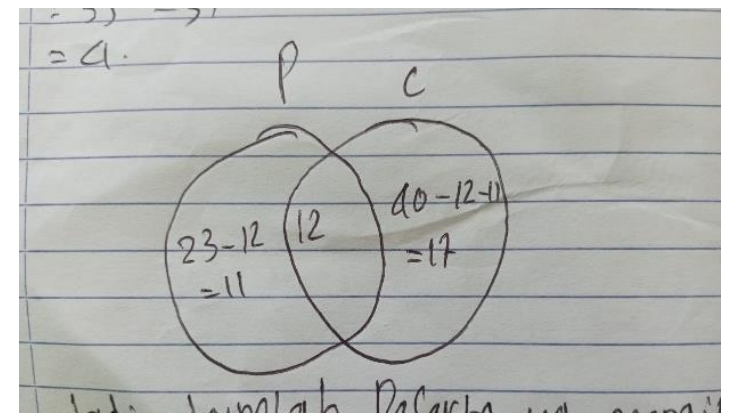

Figure 8. Answers of female students for question number 5

Figure 7 shows the results of female students' answers. Female students can express mathematical ideas in Venn diagrams or pictures or are already perfect in drawing Venn diagrams; understanding what is meant in the problem is good. While Figure 8 is the answer of male students, showing that they have been able to express mathematical ideas in pictures or Venn diagrams, but not perfect, because they are not careful in making Venn diagrams. A rectangle depicts a set of universes. The upper left is given the symbol S. This shows that female students are good enough to express mathematical ideas in pictures than male students, who cannot express mathematical concepts in diagrams or diagrams. Picture. This is in line with research conducted [17], which showed that female students were more expressive than male students. The same result is also stated by [24], wherein the aspect of drawing, female students have higher average results when compared to male students.

3. Demonstrating and explaining everyday events into mathematical models and mathematical language

For writing aspects, female students are higher than male students. The average score percentage of female students is in the medium category $72.1 \%$, so the average female communication ability is in the medium category because it is located in the middle category. In the percentage range of $65.00 \mathrm{P}<80.00$. And $61.1 \%$ of male students are included in the low category because they are in the range of $55.00 \mathrm{P}<65.00$, with the difference in the average percentage of female students and male students being $11 \%$. Subjects were selected by female and male students in questions 4 and 5 for student answers. Question number 4 is class VII-B, with 31 students participating in the competition. There were 15 participants in the Mathematics competition, 13 participants in the Science competition, and 7 participants who did not participate. Determine the number of participants taking part in both math and science competitions! Question number 5 is that there are 
40 participants in the competition. Reading poetry was followed by 23 participants; 12 participants took part in the two competitions. Determine the number of participants who participate in the short story writing competition! Explain and make a Venn diagram. Below is a picture of the students' answers.

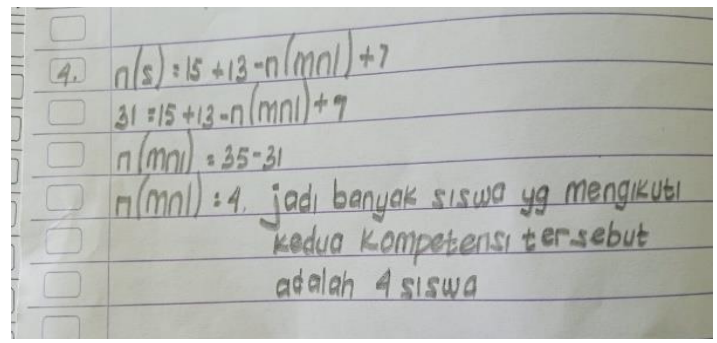

Figure 9. Answers of female students for question number 4

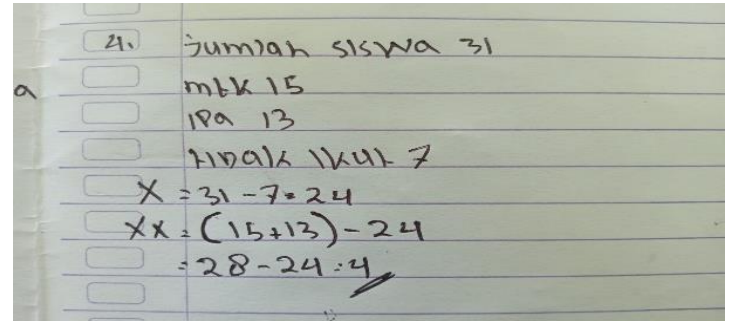

Figure 10. Answers of female students for question number 4

From Figure 9, it can be seen that the answers of female students have been able to answer the questions well and completely. The mathematical model is neat and complete, understands what is meant in the question is good, the language and conclusions used are correct. Still, the location of writing the conclusions needs to be done. Repaired again, namely, the conclusion is written at the bottom of the calculation of students' final results. In Figure 10, the male students' answers, it looks like the male students are still confused. There is still a shortage to write down what is known from the problem in writing, namely the "equals" sign. The student does not write symbols and mathematical models completely, and the solutions to the questions are not ordered and systematic, even though the answers he gets are correct.

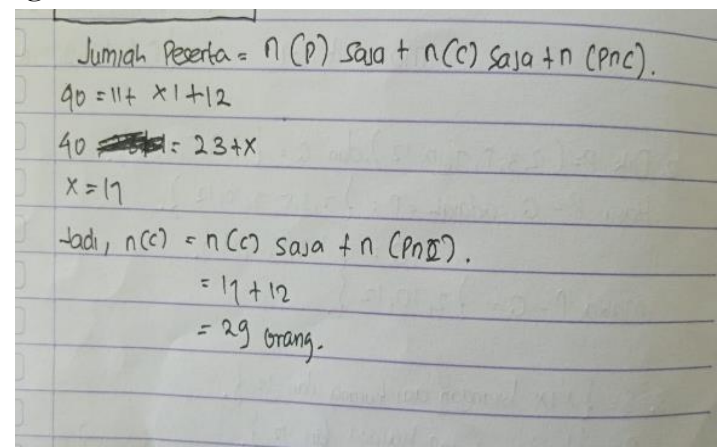

Figure 11. Answers of female students for question number 5 


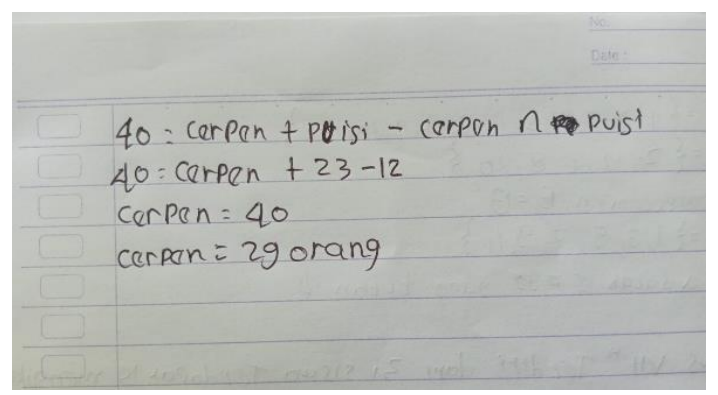

Figure 12. Answers of female students for question number 5

In figure 11, female students have been able to express everyday events in language and mathematical models, understand what is meant by the question is good, the answers given are ordered and systematic. The use of mathematical symbols is correct and the language used is also good, and the conclusions from the results of the answers are correct. Figure 12 is the answer of male students. Male students are less able to express everyday events or events in the form of language and mathematical models, do not make conclusions from the results they have obtained, work on problems that are not systematic and sequential so that there are still some steps left behind, which should be written down so that there are questions that arise when seeing the results of the completion of the male student. However, the answer to the question in question has been done for the final result, and the answer is correct.

The overall result, the mathematical communication ability of female students from the three indicators given is higher than that of male students. The highest difference is seen in the second indicator, which expresses mathematical ideas in pictures among the three indicators. On the other hand, the drawing aspect is an aspect of concern among the three aspects of communication skills given. In this aspect, the average percentage of female students and male students obtained an average of $45.72 \%$, where the range of values is in the very low category with a percentage range of $\mathrm{P}<55.00$. For the aspect of a mathematical expression, the average percentage of female and male students was $73 \%$. In the writing aspect was $66.6 \%$, the average was in the range of $65.00 \mathrm{P}<80.00$ and included in the category currently. The total average obtained by female students is $70.8 \%$, while the total average for males is $52.75 \%$, with $18.05 \%$. These results are the same as the results of research [25], which states that female students' mathematical communication skills are higher than male students. The mathematical communication ability of students from the three indicators used is higher than that of male students. It is also different from the research conducted [27], which states that in the writing aspect, the ability of male students is higher than that of female students. For drawing and expression, female students are higher than male students. Likewise, Ekasari's research (2017) in [26] states that male students are more capable of expressing mathematical ideas orally than female students. For aspects of expressing in visual and written forms, female students are more capable than male students. These differences occur because each individual's talents, requests, abilities of each individual are different from one another. According to research [28], it is stated that for students with high abilities, the information conveyed is complete in writing, while students with low abilities in writing information on questions are incomplete. Likewise, students with high abilities are fluent in communicating, while students with low abilities are less fluent in communicating. Apart from that, the researchers found at Madrasah Al Muhajirin Tapung class VII for the 2021/2022 school year, female students' communication skills from the three aspects given to the indicators of students' skills mathematical communication were superior to female students. 


\section{CONCLUSIONS AND SUGGESTIONS}

Based on the results of the research described, it can be seen that the answers of male students in answering questions tend to be shorter as if they want to finish quickly and collect them. So that it can be concluded, the mathematical communication ability of female students in the class VII set material at Madrasah Al Muhajirin Tapung is higher than that of male students. The average percentage of each indicator of communication skills is proven, which is higher for female students than male students. The difference is quite high for each indicator, namely the first indicator with a difference of $15.5 \%$, the second indicator with a difference of $27.65 \%$, and the third indicator with $11 \%$. Among the three indicators, it can be seen that the second indicator has the highest difference among the other indicators. The average gain on indicator two is also low compared to the other two indicators. If we look at the average of each aspect, then for the first aspect, namely the mathematical expression, the average percentage of male and female students is $73 \%$, including the medium category. For the second aspect, namely drawing, the average male and female students were $45.72 \%$, including the very low category. For the third aspect, namely writing, the percentage of male and female students was $66.6 \%$, including the medium category. From these results, it can be stated that for grade VII students at Mts Al Muhajirin Tapung, Academic Year 2021 - 2022, male students cannot express mathematics by stating mathematical concepts or symbols. Less able to draw by expressing mathematical ideas in the form of pictures, and less able to write by showing and explaining everyday events into mathematical models or mathematical language than female students, and obtained the average of the three indicators of mathematical communication skills given there are $70.8 \%$ for female students and $50.75 \%$ for male students. With a fairly high difference in value, namely $20.75 \%$. With a very low category for male students and a moderate category for female students.

\section{ACKNOWLEDGEMENT}

I want to thank the lecturer in charge of scientific publication courses, Mrs. Dr. Maimunah, M.Si as the first correspondent and Mrs. Yenita Roza, Ph.D as the second correspondent. Who have provided input and suggestions in compiling this article so that this article can be published.

\section{REFERENCE}

[1] S. R. Rahmayani and K. N. S. Effendi, "Kemampuan Komunikasi Matematis Siswa SMP pada Materi Himpunan,” JUDIKA (Jurnal Pendidik. UNSIKA), vol. 7, no. 1, pp. 10-19, 2019.

[2] A. Nofrianto, N. Maryuni, and M. A. Amri, "Komunikasi matematis siswa: pengaruh pendekatan matematika realistik," J. Gantang, vol. 2, no. 2, pp. 113-121, 2017.

[3] S. Aminah, T. T. Wijaya, and D. Yuspriyati, "Analisis Kemampuan Komunikasi Matematis Siswa Kelas Viii Pada Materi Himpunan,” J. Cendekia J. Pendidik. Mat., vol. 2, no. 1, pp. 15-22, 2018.

[4] Kurniawan, Yusmin, and Hamdani, "Deskripsi kemampuan komunikasi matematis siswa dalam menyelesaikan soal cerita kontekstual," J. Pendidik. dan Pembelajaran, vol. 6, no. 2, pp. 111, 2017.

[5] T. S. Wahyuni, R. Amelia, and R. Maya, "Analisis Kemampuan Komunikasi Matematis Siswa SMP Pada Materi Segiempat dan Segitiga," JKPMI J. Kaji. Pembelajaran Mat., vol. 3, no. 1, pp. 18-23, 2019.

[6] G. Kadarisma, "Penerapan Pendekatan Open-Ended dalam Meningkatkan Kemampuan Komunikasi SISWA SMP," ANARGYA J. Im. Pendidik. Mat., vol. 1, no. 2, pp. 77-81, 2018.

[7] Rahmawati., "Meningkatkan Kemampuan Komunikasi Matematis Siswa SMP dengan Menggunakan Pendekatan Kontekstual," Sesiomadika, p. 50, 2018.

[8] D. T. Lestari, E. E. Rohaeti, and E. Senjayawati, "Analisis Kesulitan Belajar Siswa SMP Kelas 
VIII dalam Menyelesaikan Soal Aritmatika Ditinjau dari Kemampuan Komunikasi Matematis,' J. Educ., vol. 1, no. 2, pp. 440-444, 2019.

[9] A. N. Hasina, E. E. Rohaeti, and R. Maya, "Analisis Kemampuan Komunikasi Siswa SMP Kelas VII dalam Menyelesaikan Soal Aritmatika Sosial,” JPMI J. Pembelajaran Mat. Inov., vol. 3, no. 5, pp. 575-586, 2020.

[10] P. Riyadi, "Analisis Kemampuan Komunikasi Matematis Siswa Ditinjau dari Gaya Belajar," Pap. Knowl. . Towar. a Media Hist. Doc., vol. 3, no. 1, pp. 12-26, 2020.

[11] T. \& Risma, "Jurnal Kajian Pembelajaran Matematika," Anal. Kemamp. Komun. Mat. siswa SMP pada Mater. segiempat dan Seg., vol. 3, no. April, pp. 18-23, 2019.

[12] M. Darkasyi, R. Johar, and A. Ahmad, "Peningkatan Kemampuan Komunikasi Matematis dan Motivasi Siswa dengan Pembelajaran Pendekatan Quantum Learning pada Siswa SMP Negeri 5 Lhokseumawe," J. Didakt. Mat., vol. 1, no. 1, pp. 21-34, 2014.

[13] M. Turmuzi and E. Kurniawan, "Analisis Kemampuan Komunikasi Matematis Mahasiswa pada Materi Geometri Analysis of Students $\hat{a} €^{\mathrm{TM}}$ Mathematical Communication Ability on Geometry Material,” vol. 11, no. April, pp. 50-61, 2021.

[14] Amni \& Kartini, "Analisis Kesalahan Siswa dalam Menyelesaikan Soal Bangun Ruang Sisi Datar Berdasarkan Teori Newman,” Juring Journal Res. Math. Learn., vol. 4, no. 1, pp. 215-224, 2021.

[15] A. Hikmah, Y. Roza, and M. Maimunah, "Analisis Kemampuan Komunikasi Matematis Siswa Smp Pada Soal Spldv,” Media Pendidik. Mat., vol. 7, no. 1, p. 29, 2019.

[16] H. Hodiyanto, "Kemampuan Komunikasi Matematis Dalam Pembelajaran Matematika," AdMathEdu J. Ilm. Pendidik. Mat. Ilmu Mat. dan Mat. Terap., vol. 7, no. 1, p. 9, 2017.

[17] S. Annisa and R. D. Siswanto, "Analisis Kemampuan Komunikasi Matematis Ditinjau Dari Gaya Kognitif dan Gender," JPPM (Jurnal Penelit. dan Pembelajaran Mat., vol. 14, no. 2, pp. 146167, 2021.

[18] R. Fauzan, U. HB, and Sukayasa, "Analisis Kemampuan Komunikasi Matematis Siswa SMP Negeri 4 Palu dalam Memahami Konsep Pecahan berdasarkan Gender yang Berkemampuan Tinggi," J. Elektron. Pendidik. Mat. Tadulako, vol. 6, no. 1, pp. 88-98, 2018.

[19] T. H. Nugraha and H. Pujiastuti, "Analisis Kemampuan Komunikasi Matematis Siswa Berdasarkan Perbedaan Gender,” Edumatica J. Pendidik. Mat., vol. 9, no. 1, pp. 1-7, 2019.

[20] S. Rofiah and U. Aripin, "Perspektif Gender Siswa SMK Pokok Bahasan Barisan dan Deret," Mat. Paedagog., vol. 4, no. 2, pp. 91-98, 2020.

[21] U. Babys, "Analisis Kemampuan Komunikasi Matematika Siswa Ditinjau dari Gender," ANARGYA J. Ilm. Pendidik. Mat., vol. 3, no. 1, pp. 25-29, 2020.

[22] W. O. Dzarian, M. Salam, and M. Anggo, "Analisis Kemampuan Komunikasi Matematis Siswa Ditinjau dari Gender (Analysis of Students $\hat{a} €^{\mathrm{TM}}$ Mathematical Communication Ability in terms of Gender) berkembang pesat dan menuntut banyak inovasi baik dari sisi materi maupun lebih . Pada hakekatnya setiap ke," J. Pembelajaran Berpikir Mat., vol. 6, no. 1, pp. 61-76, 2021.

[23] I. H. Rahman, M. M. Yassar, N. S. Fauziah, N. Rohmi, and H. Sugilar, "Analisis Kesalahan Dalam Menyelesaikan Soal Komunikasi Matematis Materi Bangun Ruang," J. Perspekt., vol. 3, no. 1, p. 47, 2019.

[24] N. H. Arifani, S. Sunardi, and S. Setiawani, "Tingkat kemampuan berpikir kreatif matematika siswa SMP kelas VIII di SMP Negeri 6 Jember, SMP Al Furqan 1, SMP Negeri 1 Rambipuji, dan SMP PGRI 1 Rambipuji," KadikmA, vol. 6, no. 2, pp. 159-172, 2015.

[25] S. P. Dewi, Maimunah, and Y. Roza, "Analisis Kemampuan Komunikasi Matematis Siswa Pada materi lingkaran di tinjau dari perbedaan gender," J. Kependidikan, vol. 7, no. 3, pp. 699-707, 2021.

[26] N. A. Maryamah, "Analisis Kemampuan Komunikasi Matematis Siswa Berdasarkan Gender di Kelas VII SMP Daarul Aitam Palembang,” UIN Raden Fatah Palembang, 2019.

[27] T. H. Nugraha and H. Pujiastuti, "Analisis Kemampuan Komunikasi Matematis Siswa Berdasarkan Perbedaan Gender Analysis of Students Mathematical Communication Skills Based on Gender Differences," Edumatica J. Pendidik. Mat., vol. 9, no. 1, pp. 1-7, 2019. 
[28] N. W. Nurdiansyah, "Profil Komunikasi Matematika Tulis Siswa Smp Dalam Memecahkan Masalah Matematika Ditinjau Dari Kemampuan Matematika Siswa," MATHEdunesa, vol. 9, no. 2, pp. 442-454, 2020.

\section{BIOGRAPHY}

Rodhitul Amni

Rodhitul Amni studied at (1) SD Negeri 007 Pantaicermin (2) MTs Darul Hasanah Pantaicermin, (3) SMA Negeri 2 Tapung, (4) Universitas Islam Negeri Sulthan Syarif Kasim Riau. Currently teaching at Madrasah Tsanawiyah Al Muhajirin Tapung. Contact Person: 085265991430. Email: rodhitul.amni7398@grad.unri.ac.id 